\title{
Mimicry of Dopamine 1 Receptor Signaling with Cell-Penetrating Peptides
}

\author{
Nicola Lorenzon ${ }^{1}$ (I) Maxime Gestin ${ }^{1}$ (D) Ülo Langel ${ }^{1,2}$ (D)
}

Accepted: 9 April 2020 / Published online: 25 April 2020

(c) The Author(s) 2020

\begin{abstract}
In this study, through the use of protein mimicry, a peptide was developed to activate the dopamine 1 receptor signaling pathway from the inside of the cell and in absence of the natural extracellular ligand. The sequence was initially derived from the intracellular interaction site between the activated receptor and the alpha domain of its associated G-protein and subsequently modified to increase its cell-penetrating properties. The peptide was then synthesized via solid phase peptide synthesis, purified and tested on cell models. This novel lipopeptide proved to be capable of efficiently ubiquitously penetrating the cell without the need for transfection agents or chiral recognition by specific pathways. Furthermore, the peptide induced the cellular response normally achieved through the activation of the receptor in cells that had not been treated with the natural ligand. The peptide could work as a candidate substitute to L-DOPA, leading the way for a peptides-based treatment for Parkinson's disease.
\end{abstract}

Keywords Protein mimicry · Cell penetrating peptides · Pepducins · Dopamine 1 receptor · Protein-protein interaction · Structure-based design

\section{Introduction}

Cell-penetrating peptides (CPPs) are a class of short generally cationic and/or amphipathic peptides capable of internalizing the cell via different mechanisms (Bechara and Sagan 2013). This property is bestowed by the presence of prevalently positively-charged and hydrophobic amino acid residues in the sequence, which interact with the negativelycharged components of the lipidic bilayer of the cell membrane (Madani et al. 2011).

The use of CPPs to transfect cargoes (such as small molecules, small proteins, peptides or nucleic acids) into the cell has been widely established ( $\mathrm{Li}$ et al. 2015; Singh et al.

Electronic supplementary material The online version of this article (https://doi.org/10.1007/s10989-020-10066-y) contains supplementary material, which is available to authorized users.

Nicola Lorenzon

nicola.lorenzon@crg.eu

1 Department of Biochemistry and Biophysics, Stockholm University, 10691 Stockholm, Sweden

2 Laboratory of Molecular Biotechnology, Institute of Technology, University of Tartu, Nooruse, 50411 Tartu, Estonia
2018; Kurrikoff and Langel 2019). As vectors, CPPs can be used either in complex with the molecules of interest (e.g. forming electrostatically-bound particles that dissociate once transfected) or be covalently conjugated to them (Gagat et al. 2017). In particular, by conjugating lipidated CPPs with an amino acid sequence resembling parts of a functional full-length protein, chimeric peptides, generally labeled as 'pepducins', can be produced. Thanks to these functional domains on their backbone, pepducins are capable, once internalized, of specifically interfering with protein-protein interactions by competitively binding to the target protein (Zhang et al. 2015). This has been used in the past, for example, to modulate the response of tyrosine-kinase and angiotensin receptors and clinical trials have recently started for an antiplatelet-agent-acting pepducin (Yu et al. 2010, 2015; Gurbel et al. 2016). Furthermore, pepducins represent a promising class of allosteric G-protein coupled receptors (GPCRs) modulators, overcoming the selectivity problem associated with the use of extracellular ligands (Eglen and Reisine 2011). For example, one neurotransmitter (NT) is often capable of inducing multiple and opposite responses depending on the receptor it binds to, which is why the specific modulation of a NT-driven signaling cascade represents 
one of the most important challenges in modern neuropharmacology (Franco 2009).

In patients suffering from Parkinson's disease, the progressive loss of dopaminergic neurons in the brain is compensated for by the administration of L-DOPA, a dopamine precursor. However, long term treatment with L-DOPA leads to numerous side effects, including the L-DOPA-induced dyskinesia (LID) (Pandey and Srivanitchapoom 2017). LID originates from an over sensitization of the dopamine 1 dopamine receptor (DRD1), a Gs-protein GPCR, which leads to the pathological response to L-DOPA treatment (Santini et al. 2012). The use of an ad hoc developed pepducin would represent a novel treatment for LID, for it would allow modulating the activity of DRD1 while bypassing the malfunctioning receptor. In particular, acting upon the first intracellular step of the DRD1 signaling cascade, id est, the DRD1/Gos-protein interaction, could allow for the modulation of the whole pathway. However, so far, no pepducins were ever developed for this purpose.

In this study, a lipidated cell-penetrating peptide mimicking the Gs-binding domain of the DRD1 was developed to target the DRD1/Gos-protein interaction.

\section{Materials and Methods}

\section{Design of the Peptides}

To develop a pepducin modulating the DRD1 signaling pathway, the DRD1/Gos-protein interaction was targeted. A 2005 study by Kang et al. on the interaction between the intracellular loops of the human serotonin receptor type 6 (5- $\mathrm{HT}_{6}$, structurally and functionally similar to DRD1) and the $\alpha$-subunit of the Gs protein, identified the interaction domain to be located on the C-terminal portion of the third intracellular loop (IL3) of 5- $\mathrm{HT}_{6}$, pinpointing two lysine residues (K262 and K265) to be crucial for the Gos binding to the receptor (Kang et al. 2005). From a comparison between the sequences of the various Gs-coupled catecholamine receptors, the C-terminal portion of the IL3 resulted to be highly conserved (Fig. 1). In particular Gos-coupled receptor presented two lysine residues analogous of the aforementioned $\mathrm{K} 262$ and $\mathrm{K} 265$ of $5-\mathrm{HT}_{6}$. Therefore, this portion of the receptor was used to generate the CPP/pepducins of interest.

At first, computational estimation of the cell penetrating properties of the designed peptides was obtained using a CPP-prediction program: KELM-CPPpred. (Pandey et al. 2018) Sequences predicted to work as CPPs were then synthesized and tested as presented below. A lipid tail was added to the amino acid backbone to increase the likelihood of cell penetration (Lehto et al. 2017).

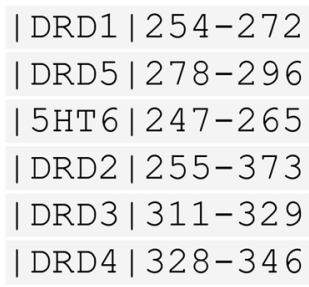

Conserved

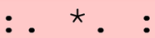

Fig. 1 Sequence alignment of the C-terminal of the IL3 of dopaminergic and serotonergic receptors. DRD1, DRD5 and 5- $\mathrm{HT}_{6}$ are Gs-protein coupled receptors, whereas DRD2, DRD3 and DRD4 are Gi-coupled. The alignment shows highly conserved residues amongst receptors coupled to the same G-protein. In bright red: lysine residues crucial for Gos subunit binding to the receptor as stated by Kang et al. (2005). Alignment performed via T-Coffee software (Notredame et al. 2000) (Color figure online)

Peptides generated from the aforementioned portion of DRD1 were labeled as 'D-1-R-Mo', from 'Dopamine 1 dopamine Receptor Modulators' (later contracted to 'Dyro' for simplicity) followed by a serial number (Table 1). The fluorescent-probe-labeled version of a peptide that was employed during microscopy was labeled with an asterisk (*).

\section{Synthesis}

The peptides were synthetized via Solid Phase Peptide Synthesis (SPPS) using fluorenylmethyloxycarbonyl (Fmoc) chemistry protocols. The synthesis was performed either manually or by microwave-assisted SPPS (Biotage Alstra+, Biotage AB, Uppsala, Sweden) in dimethylformamide (DMF). H-Rink-Amide-ChemMatrix resin was used as solid support. Synthesis method and resin loading varied according to the sequence: due to the cumulative decrease in yield at every step of the synthesis, longer or sterically hindered peptides were synthetized manually on low-loading solid supports.

The carboxylic groups were activated with HCTU/ HOBt (2-(6-chloro-1H-benzotriazole-1-yl)-1,1,3,3-tetramethylaminium-hexafluorophosphate/6-chloro-1-hydroxy benzo-triazol; manual synthesis) or with DIC/Oxyma ( $N, N^{\prime}$-diisopropylcarbodiimide /Ethyl cyanohydroxyiminoacetate; microwave-assisted synthesis). Manual coupling of the amino acids was performed at room temperature. Couplings in microwave-assisted SPPS were performed at $70{ }^{\circ} \mathrm{C}$, although to avoid undesired side reactions, coupling of histidine, cysteine or arginine residues was performed at a maximum of $49^{\circ} \mathrm{C}$. Coupling times ranged from 35 to 90 min, depending on the position and nature of the coupled residue. Deprotection steps were performed in $20 \%$ piperidine. The fluorescent probe (5(6)-Carboxyfluorescein (FAM) 
was coupled to the side chain of the penultimate lysine residue from the N-terminus; for this purpose, a 4-Methyltrityl (Mtt)-protected lysine was integrated in the peptide, allowing for selective deprotection via 1\%TFA/2.5\%TIS/Dichloromethane cocktail.

The peptides were cleaved using a 95\% Trifluoracetic acid (TFA) $/ 2.5 \%$ water $/ 2.5 \%$ triisopropylsilane cocktail for 3-4 $\mathrm{h}$ and precipitated dropwise in ice-cold diethylether $\left(\mathrm{Et}_{2} \mathrm{O}\right)$. The obtained crude peptide was dried and then purified via high performance liquid chromatography (HPLC) on a C4, $\mathrm{C} 8$ or $\mathrm{C} 18$ column using a gradient of acetonitrile (ACN) / water containing $0.1 \%$ TFA. The purity and correct identity of the processed peptide products was assessed via analytical HPLC and by electrospray-time-of-flight mass spectrometery (ESI-TOF). After the purification and qualitative analysis, the peptides were lyophilized using a freeze-dryer, reconstituted in ultra-pure water and stored at $-20{ }^{\circ} \mathrm{C}$ before use.

\section{Cell Lines}

To assess whether the peptides had an effect on the DRD1mediated signaling pathway, the SH-SY5Y cell line was employed, for, contrarily to the control cell line HeLa, SHSY5Y cells express the aforementioned receptor. Furthermore, the neuroblastoma SH-SY5Y cell line is commonly used in PD research, whereas the adenocarcinoma HeLa cell line is widely employed in molecular biology research, assessing these cell lines as ideal model organisms for the purpose of this study (Landry et al. 2013; Xicoy et al. 2017). The cell line strains were already available in the laboratory, and the presence/absence of the receptor was assessed via real-time quantitative polymerase chain reaction (RT-qPCR) performed on cDNA obtained by retro-transcription of the total mRNA derived from the cell lines.

SH-SY5Y cells were grown in Minimum Essential Medium (MEM) (Sigma Aldrich Sweden), supplemented with $1 \times$ non-essential amino acids (NEAA), $1 \times$ L-glutamate, $10 \%$ fetal bovine serum (FBS), $200 \mu \mathrm{g} / \mathrm{mL}$ streptomycin and $200 \mathrm{U} / \mathrm{mL}$ penicillin (Invitrogen, Sweden). The medium was changed every 2 days, whereas cells were split 1 to 10 every 7 days.

HeLa cells were grown in Dulbecco's Modified Eagle Medium (DMEM) (Sigma Aldrich Sweden), supplemented with $4.5 \mathrm{~g} / \mathrm{L}$ glucose, $1 \times$ NEAA, $1 \times$ L-glutamate, $10 \%$ FBS, $200 \mu \mathrm{g} / \mathrm{mL}$ streptomycin and 200U/mL Penicillin (Invitrogen, Sweden). The medium was changed every 2 days, whereas cells were split 1 to 10 every 4 days.

\section{Epi-fluorescence Microscopy}

To establish the peptides function as CPPs, epi-fluorescence microscopy imaging was used. $15 \mathrm{k}$ cells were seeded in each well of a microscopy glass bottom black 96-well plate, left attaching overnight and then treated with various concentration of the fluorophore-conjugated peptide (ranging from $10 \mathrm{nM}$ to $50 \mu \mathrm{M})$ at different points in time $(1 \mathrm{~h}, 3$ h, $24 \mathrm{~h}$ ), followed by $15 \mathrm{~min}$ incubation with the nuclear stain (Hoechst 33342). To remove excess stain from the plate, the wells were then rinsed twice using Opti-MEM Reduced Serum Medium. To ensure cell viability, $200 \mu \mathrm{L}$ of the medium were added to each well before the microscopy.

Imaging was performed using a Leica DM/IRBE 2 epi-fluorescence microscope with $10 \times, 43 \times$ dry or $43 \times$, $63 \times 1.4$ NA oil immersion objective. Samples were kept at $37{ }^{\circ} \mathrm{C}$ at all times. Images were recorded via a Hamamatsu Orca-ER CCD camera. The system was controlled by MicroManager (Edelstein et al. 2014). Images were then processed using Image J (Rueden et al. 2017).

\section{Toxicity Assay}

The Pierce LDH Cytotoxicity Assay kit (Thermo Fisher) was used to assess the potential cytotoxic effects of the peptides due to the disruption of the membrane during cell penetration. The kit measures the quantity of lactate dehydrogenase (LDH, a cytosolic enzyme) present in the medium (Decker and Lohmann-Matthes 1988). Untreated cells were used as negative control, whereas Triton-X-treated-cells were used as positive control (for, being a detergent, it induces the complete disruption of the membrane and the release of LDH in the medium). Cells were treated with different concentrations of the peptide (ranging from $10 \mathrm{nM}$ to 100 $\mu \mathrm{M})$ at different time points ( 2 to $24 \mathrm{~h}$ ). Data were plotted using GraphPad Prism 6.01 and normalized to the controls (Swift 1997).

\section{Dynamic Light Scattering and $\zeta-$ Potential}

To determine the physical-chemical properties of the peptides and their propensity to particle formation, the hydrodynamic diameter and the $\zeta$-potential of the peptides were measured using a Zetasizer Nano ZS (Malvern Instruments, United Kingdom). Measurements were performed at 37 ${ }^{\circ} \mathrm{C}$ on $600 \mu \mathrm{L}$ of Opti-MEM containing various concentrations of the peptide $(1 \mu \mathrm{M}, 5 \mu \mathrm{M}$ and $10 \mu \mathrm{M})$ in Malvern Disposable Folded Capillary Zeta cells DTS1070 cuvettes. Opti-MEM was chosen for the characterization for it is the medium in which the cAMP experiments were performed.

\section{CAMP Assay}

DRD1 binds to the alpha subunit of a Gs-protein, which in turn activates the adenylyl cyclase (AC), increasing the production of cyclic-adenosine-monophosphate (cAMP), which is then employed as second messenger by the cell (Neve et al. 
2004). To establish if cell treatment with the peptides led to variations in the levels of cAMP, indicating an effect on the DRD1 signaling pathway, the cAMP-Glo ${ }^{\text {TM }}$ Max Assay kit (Promega) was employed. A clear bottom white 96-well plate was seeded with $15 \mathrm{k}$ cells/well. Half of the wells were treated with the peptide at various concentrations, half of the wells, instead, were treated with both the peptide at various concentrations and $0.25 \mathrm{mM}$ dopamine hydrochloride. This allowed to test whether the possible variations would occur only in presence of dopamine (hence only when the receptor was activated) or if the peptide was capable of interfering with the pathway in other ways. Untreated cells were used as negative control, whereas cholera toxin [capable of irreversibly activating the Gs $\alpha$ (Liu et al. 1992)] was used as positive control. The increase in cAMP levels derived from the activation of the DRD1-pathway after dopamine binding was measured on cells treated solely with $0.25 \mathrm{mM}$ of dopamine hydrochloride, a response-inducing concentration (Colombo et al. 2016) in an acceptable cytotoxic range (SOFIAN et al. 2014). All treatments were performed at different time points (1 h, 2 or 4 h) in Opti-MEM Reduced Serum Medium supplied with IBMX and Ro 20-1724 (two cyclic nucleotide phosphodiesterase inhibitors, to prevent the degradation of the cAMP by native enzymes). The assay was then performed according to the manufacturers' instructions. Data were plotted using GraphPad Prism and normalized to the controls (Swift 1997).

\section{Results}

\section{Dyro 1 Penetrates the Cell Membrane}

Under Epi-fluorescence microscopy, Dyro $1 *$ showed cellpenetrating properties already at $1 \mu \mathrm{M}$ after $1 \mathrm{~h}$ of treatment (Fig. 2). Dyro 2*, the unstearylated form of Dyro 1, instead, was not capable of crossing the cell membrane, suggesting that the lipid tail is implicated in the translocation mechanism.

Stearylated peptides derived from a larger portion of the DRD1-IL3 (from K261 to S275 onwards) were not soluble in water and were therefore discarded. Substitution of the lipid tail with a polyarginine tail (a known CPP (Fuchs and Raines 2005)) did not allow for solubilization in water either, indicating that the problem originates from the sequence itself.

\section{Assessing the Working Concentration}

Utilizing the aforementioned Pierce LDH Cytotoxicity Assay, the concentration of Dyro 1 sufficient to induce rupturing of the membrane in half of the cells treated (EC50) was determined to be $6.72 \mu \mathrm{M}$ after $24 \mathrm{~h}$ (Fig. 3) and 100 $\mu \mathrm{M}$ after $2 \mathrm{~h}$ (Supplementary Fig. S1). Concentrations that induced less than $20 \%$ of membrane rupture were deemed to be acceptable working concentrations for that or shorter treatment times.

\section{Dyro 1 Aggregates in Particles}

DLS and $\zeta$-potential measurements were performed to characterize Dyro 1 in solution, as stated in the Material and methods section. The hydrodynamic diameter measurements revealed that Dyro 1 forms particles, whose size increases exponentially depending on the concentration (Supplementary Fig. S2). The formation of particles was confirmed also by the $\zeta$-potential, which assessed the peptide to be in rapid coagulation range at the concentrations of interest (Maha et al. 2016). This suggests that hydrophobic interactions between the lipid tails of Dyro 1 molecules led to the formation of particles. Given that numerous CPP models rely on the interaction between lipopeptidic aggregates and the cell membrane to explain the mechanism of cell penetration, these data can provide an explanation on why the unstearylated versions of the peptide proved not to be capable to enter the cell.

\section{Dyro 1 Selectively Increases cAMP Levels in Cells Expressing DRD1}

To study the possible effects of Dyro 1 on the dopamine signaling pathway, variations in cAMP levels were measured after treatment. Experiments were performed as stated in Material and methods. SH-SY5Y cells (expressing DRD1) showed a concentration-dependent increase in cAMP levels after treatment with the peptide (Supplementary Fig. S3). In particular, a $4 \mathrm{~h}$ treatment was sufficient to induce an up to $37 \%$ increase in cAMP levels compared to the controls (untreated cells and cholera toxin treated cells; Fig. 4). This is almost a 2-fold increase compared to the $23.2 \%$ increase in cAMP levels induced by DRD1 activation via dopaminebinding measured by treating cells solely with $0.25 \mathrm{mM}$ dopamine hydrochloride for $4 \mathrm{~h}$ and comparing the data to the aforementioned controls (Fig. 4). This effect was not observed in the control cell line (HeLa cells, not expressing DRD1), which showed no significant increase in cAMP levels after $4 \mathrm{~h}$ of treatment with Dyro 1 (Supplementary Fig. S4), suggesting that the presence of the receptor plays a role in the peptide-induced cAMP production.

Furthermore, SH-SH5Y cells that were co-treated for $4 \mathrm{~h}$ with different concentrations of Dyro 1 and $0.25 \mathrm{mM}$ dopamine hydrochloride, showed a constant $\approx 25 \%$ concentrationindependent increase in cAMP levels (Supplementary Fig. S5) similar to the $+23.3 \%$ cAMP effect observed in the cells that had been treated solely with dopamine. This effect was 


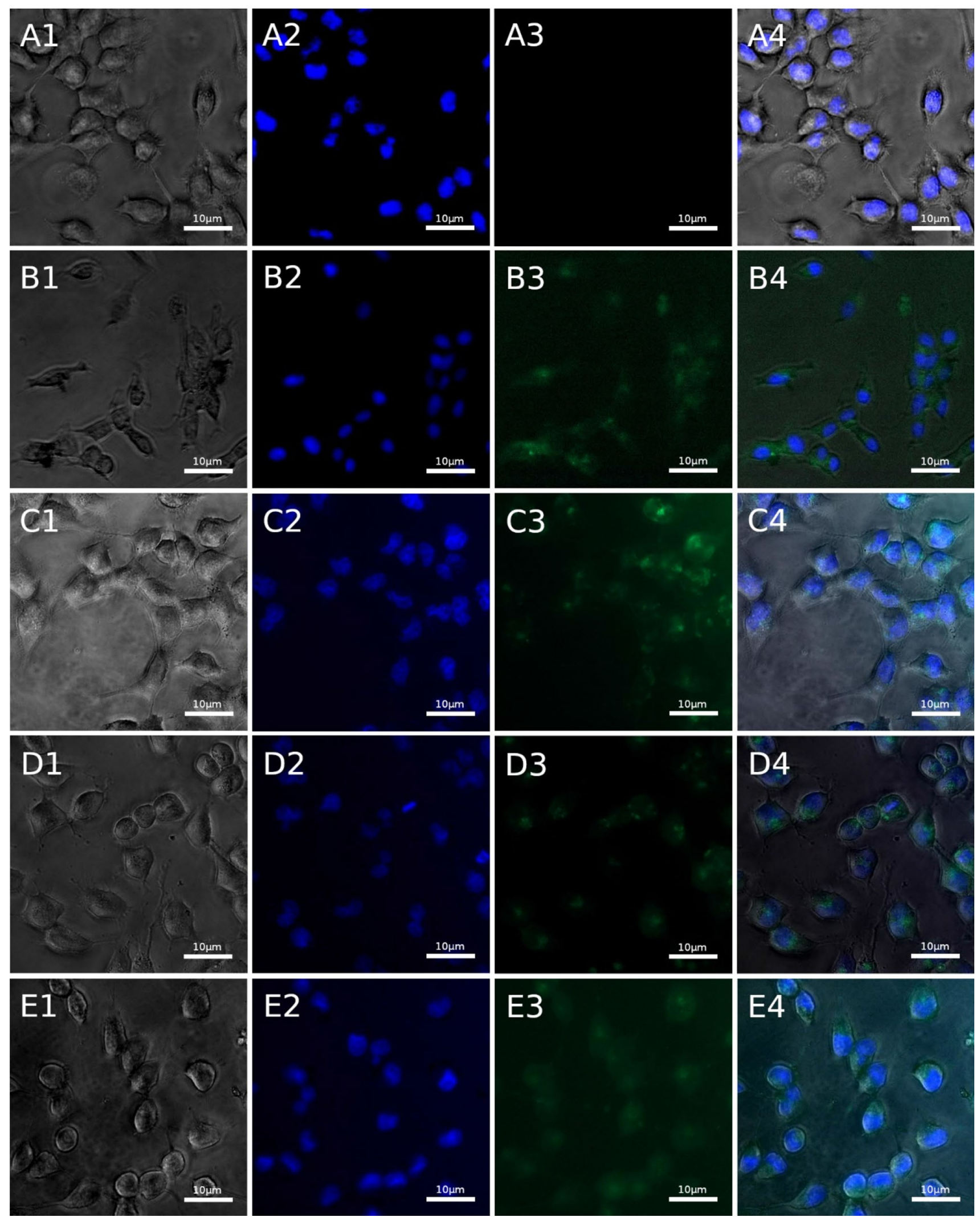

Fig. 2 Dyro $1^{*}$ on HeLa cells. Columns from left to right: Transmission channel, Hoechst channel (nuclear stain), fluorescein channel, merged channels. Rows: a cells treated with $1 \mu \mathrm{M}$ carboxyfluorescein solution for $1 \mathrm{~h}$ (Control); b cells treated with $1 \mu \mathrm{M}$ Dyro $1 *$ for $1 \mathrm{~h}$; c cells treated with $10 \mu \mathrm{M}$ Dyro $1^{*}, 1 \mathrm{~h}$ treatment; d $1 \mu \mathrm{M}$ Dyro $1^{*}$, $24 \mathrm{~h}$ treatment; e $10 \mu \mathrm{M}$ Dyro $1 * ; 24 \mathrm{~h}$ treatment 


\section{Cytotoxicity of Dyro 1 after 24hrs}

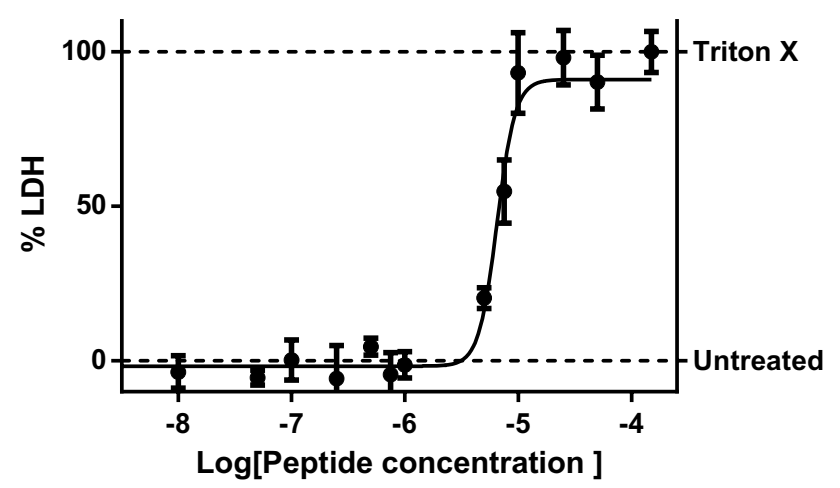

Fig. 3 Cytotoxicity of Dyro 1 on SH-SY5Y cells after $24 \mathrm{~h}$ treatment. SH-SY5Y cells were treated with increasing concentrations of Dyro 1 for $24 \mathrm{~h}$. The quantity of lactate dehydrogenase (LDH, a cytosolic enzyme) present in the medium was measured as an indicator for membrane disruption and cell death. Data were normalized to the controls: untreated cells were used as negative control (physiological release of LDH in the cell medium; 0\%), whereas cells treated with Triton $\mathrm{X}$ were used as the positive control (being a detergent, Triton $\mathrm{X}$ induces membrane disruption and complete LDH release; 100\%). Control samples were examined via microscopy before LDH measurements to check for viability. The experiment was performed three times in quadruplicates ( $\mathrm{p}$ value $=0.0012$ ). Calculated $\mathrm{EC} 50=6.72$ $\mu \mathrm{M}$

\section{SH-SY5Y cells CAMP levels, $4 \mathrm{hrs}$ treatment}

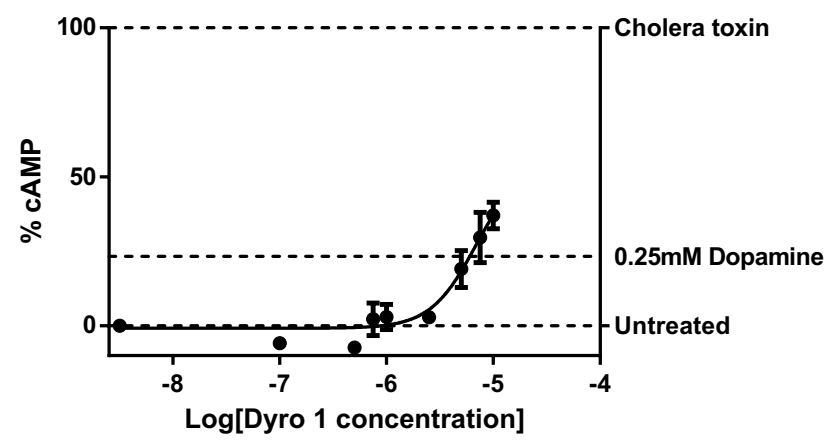

Fig. 4 cAMP levels of SH-SY5Y cells after $4 \mathrm{~h}$ treatment. SH-SH5Y cells (expressing DRD1) were treated with increasing concentrations of Dyro 1 for $4 \mathrm{~h}$. In order not to incur in the peptide cytotoxic effect, $10 \mu \mathrm{M}$ Dyro 1 was the maximum peptide concentration used. Data were normalized to the controls: untreated cells $(0 \%)$ and choleratoxin-treated cells (100\%; cholera toxin is known to irreversibly activate $\mathrm{AC}$, thereby setting the maximal cAMP production levels). Cells treated solely with $0.25 \mathrm{mM}$ dopamine hydrochloride were employed to measure the variation of cAMP levels following DRD1 response to ligand binding (23.2\% in the graph). Samples were examined via microscopy before cAMP level measurements to check for viability. The experiment was performed four times in quintuplicates for statistical significance (use of one-tail multiple T-tests)
Table 1 Sequences of the peptides derived from the DRD1 IL3

\begin{tabular}{|c|c|}
\hline Dyro 1 & Stearyl-KRETKVLK-NH ${ }_{2}$ \\
\hline Dyro $1 *$ & Stearyl-KRETK( $\varepsilon-5(6)$ carboxyfluorecein $)$ VLK-NH \\
\hline Dyro 2 & KRETKVLK-NH $_{2}$ \\
\hline Dyro $2 *$ & $\operatorname{KRETK}\left(\varepsilon-5(6)\right.$ carboxyfluorecein)VLK-NH ${ }_{2}$ \\
\hline Dyro 3 & Stearyl-PESSFKMSFKRETKVLKTLS-NH ${ }_{2}$ \\
\hline Dyro 4 & Palmitoyl-PESSFKMSFKRETKVLKTLS-NH ${ }_{2}$ \\
\hline Dyro 5 & RRRRRPESSFKMSFKRETKVLKTLS-NH ${ }_{2}$ \\
\hline Dyro 6 & PESSFKMSFKRETKVLKTLS-NH ${ }_{2}$ \\
\hline Dyro 7 & Stearyl-KMSFKRETKVLKTLS-NH ${ }_{2}$ \\
\hline
\end{tabular}

therefore attributable to the presence of dopamine in the treatment mixture and not to the peptide.

\section{Discussion}

Parkinson's disease is characterized by the progressive loss of dopaminergic neurons in the periphery and in the central part of the nervous system. Patients suffering from this disorder are commonly treated with L-DOPA, which is capable of temporarily compensating for the loss of endogenous dopamine. However, long-term L-DOPA treatment overcharges the remaining dopaminergic receptors, leading to their over sensitization and the consequential onset of numerous side-effects. In particular L-DOPA-induced-dyskinesia (LID) originates from the over sensitization of the dopamine 1 receptor (DRD1) (Santini et al. 2012). Bypassing the malfunctioning receptors by targeting directly the dopaminergic pathways from the inside of the cell might represent a novel approach to contrast the occurrence of these side effects. Pepducins, i.e. lipidated cell-penetrating peptides designed to mimic the active site of a protein of interest, are good candidates for this purpose.

In this study, stearylated peptides derived from the intracellular active site of the dopamine 1 receptor, were designed to target the DRD1/Gos-protein interaction. Following previous studies on pepducins targeting the GPCR/ $\mathrm{G} \alpha \mathrm{s}$ interaction, the portion of interest was individuated in the third intracellular loop (IL3) of DRD1 (O'Callaghan et al. 2012). Furthermore, from a comparison between the sequences of various Gs-coupled catecholamine receptors (Fig. 1), the last portion of the IL3 resulted to be the most conserved. In particular, two lysine residues (K269 and K272) were referable to the K262 and K265 residues of the IL3 of serotonin receptor type 6, which are known to be crucial in the receptor/G-protein interaction (Kang et al. 2005). Dyro 1, the C-terminal stearylated peptide derived from the K265-K272 portion of the DRD1-IL3, proved to be the best candidate. 
Under epi-fluorescent microscopy, the fluoresceinlabeled Dyro $1^{*}$ was assessed to work as a cell-penetrating peptide. However, its unstrearylated version proved not to be capable of autonomously crossing the cell membrane, suggesting that the lipid tail plays a crucial role in the translocation mechanism. This is consistent not only with previous studies on CPPs, where lipidation is often used to increase the efficiency of the penetration (Lehto et al. 2017), but on pepducins in general, where the presence of the tail is a conditio sine qua non the peptide can work as a CPP on its own (Zhang et al. 2015). Furthermore, from the DLS analysis and $\zeta$-potential measurements, Dyro 1 proved to be capable to form particles in solution. This, together with the necessity for the lipid tail to enter the cell, suggested that the translocation mechanism relies on hydrophobic interactions between the lipopeptidic particles and the cell membrane, in line with the most common CPP penetration mechanism hypothesis (Bechara and Sagan 2013).

After treatment, Dyro 1 selectively induced a concentrationdependent increase in cAMP levels in cells expressing DRD1, while presenting no effect on the control cell line, which did not express the receptor. This indicated that the presence of the receptor was necessary to induce the cellular response to treatment, which is in line with previous in vivo studies on pepducins activity performed on knock-out mice (Kaneider et al. 2007; Sevigny et al. 2011). This increase is comparable to the one observed in a 2014 study by Carr et al., where two pepducins derived from the IL3 of the beta-adrenergic 2 receptor (a Gos-coupled GPCR) were capable of inducing an up to $+40 \%$ concentration-dependent effect on cAMP levels in cells expressing the receptor (Carr et al. 2014).

All cAMP measurements were performed using the assessed safe working concentration range of Dyro 1. This allowed the detection of the concentration-dependent effect of the peptide in relation to the natural ligand, but not the building of a standard dose-response curve (and therefore the calculation of the IC50). Using higher concentrations for the sake of building a standard curve would have not made sense from a biological point of view, for the alterations in cAMP levels would have not derived solely in response to the modulation of the pathway of interest, but also from the activation of the apoptotic pathway (of which cAMP is a well-known second messenger (Insel et al. 2012)) due to the CPP-induced perturbation of the membrane (Saar et al. 2005). The curves obtained from these experiments were sufficient for the purpose of this study.

Furthermore, the Dyro 1 seemingly showed no effect on cells that had been co-treated with dopamine hydrochloride, an agonist of DRD1, suggesting that the peptide does not have an effect on an already activated signaling pathway. This could be explained in the light of the mechanism of action of the peptide: pepducins have been found to be capable of mimicking and/or inducing the intracellular on-conformation of the receptor of interest (O'Callaghan et al. 2012). An already-active receptor would therefore not be affected by the action of these peptides.

In conclusion, experiments on blood brain barrier (BBB) models might be used to assess the ability of Dyro 1 to enter the central nervous system. If successful, mice models could be employed to study its effects on the brain and in particular if it could be used as a novel drug or co-treatment for patients suffering from PD and LID which require the DRD1-signally pathway to be artificially activated, but where the receptor is not properly functioning and the use of extracellular ligands has proved to induce major side effects. In particular, the peptide might be employed to substitute partially, or, in combination with similar peptides, completely, L-DOPA in the treatment of Parkinson's disease.

Acknowledgements Open access funding provided by Stockholm University. Study supported by the Swedish Research Council (Natural and Engineering Sciences).

Author Contributions NL conceived the study, ÜL supervised the study, NL designed and performed the experiments, MG participated in the experiments, NL wrote and revised the manuscript, MG and ÜL contributed to revise the manuscript. All authors have read and approved the final manuscript.

Open Access This article is licensed under a Creative Commons Attribution 4.0 International License, which permits use, sharing, adaptation, distribution and reproduction in any medium or format, as long as you give appropriate credit to the original author(s) and the source, provide a link to the Creative Commons licence, and indicate if changes were made. The images or other third party material in this article are included in the article's Creative Commons licence, unless indicated otherwise in a credit line to the material. If material is not included in the article's Creative Commons licence and your intended use is not permitted by statutory regulation or exceeds the permitted use, you will need to obtain permission directly from the copyright holder. To view a copy of this licence, visit http://creativecommons.org/licenses/by/4.0/.

\section{References}

Bechara C, Sagan S (2013) Cell-penetrating peptides: 20 years later, where do we stand? FEBS Lett 587:1693-1702. https://doi. org/10.1016/j.febslet.2013.04.031

Carr R, Du Y, Quoyer J, Panettieri RA, Janz JM, Bouvier M, Kobilka BK, Benovic JL (2014) Development and characterization of pepducins as gs-biased allosteric agonists. J Biol Chem 289:3566835684. https://doi.org/10.1074/jbc.M114.618819

Colombo ML, McNeil S, Iwai N, Chang A, Shen M (2016) Electrochemical detection of dopamine via assisted ion transfer at nanopipet electrode using cyclic voltammetry. J Electrochem Soc 163:H3072-H3076. https://doi.org/10.1149/2.0091604jes

Decker T, Lohmann-Matthes M-L (1988) A quick and simple method for the quantitation of lactate dehydrogenase release in measurements of cellular cytotoxicity and tumor necrosis factor (TNF) activity. J Immunol Methods 115:61-69. https://doi. org/10.1016/0022-1759(88)90310-9 
Edelstein AD, Tsuchida MA, Amodaj N, Pinkard H, Vale RD, Stuurman N (2014) Advanced methods of microscope control using $\mu$ Manager software. J Biol Methods 1:e10. https://doi. org/10.14440/jbm.2014.36

Eglen RM, Reisine T (2011) GPCRs revisited: new insights lead to novel drugs. Pharmaceuticals 4:244-272. https://doi.org/10.3390/ ph4020244

Franco R (2009) G-protein-coupled receptor heteromers or how neurons can display differently flavoured patterns in response to the same neurotransmitter. Br J Pharmacol 158:23-31. https://doi.org /10.1111/j.1476-5381.2009.00181.x

Fuchs SM, Raines RT (2005) Polyarginine as a multifunctional fusion tag. Protein Sci Publ Protein Soc 14:1538-1544. https://doi. org/10.1110/ps.051393805

Gagat M, Zielińska W, Grzanka A (2017) Cell-penetrating peptides and their utility in genome function modifications (Review). Int $\mathbf{J}$ Mol Med 40:1615-1623. https://doi.org/10.3892/ijmm.2017.3172

Gurbel PA, Bliden KP, Turner SE, Tantry US, Gesheff MG, Barr TP, Covic L, Kuliopulos A (2016) Cell-penetrating pepducin therapy targeting PAR1 in subjects with coronary artery disease. Arterioscler Thromb Vasc Biol 36:189-197. https://doi.org/10.1161/ ATVBAHA.115.306777

Insel PA, Zhang L, Murray F, Yokouchi H, Zambon AC (2012) Cyclic AMP is both a pro-apoptotic and anti-apoptotic second messenger. Acta Physiol Oxf Engl 204:277-287. https://doi.org/10.111 1/j.1748-1716.2011.02273.x

Kaneider NC, Leger AJ, Agarwal A, Nguyen N, Perides G, Derian C, Covic L, Kuliopulos A (2007) "Role reversal" for the receptor PAR1 in sepsis-induced vascular damage. Nat Immunol 8:13031312. https://doi.org/10.1038/ni1525

Kang H, Lee WK, Choi YH, Vukoti KM, Bang WG, Yu YG (2005) Molecular analysis of the interaction between the intracellular loops of the human serotonin receptor type 6 (5-HT6) and the $\alpha$ subunit of GS protein. Biochem Biophys Res Commun 329:684692. https://doi.org/10.1016/j.bbrc.2005.02.040

Kurrikoff K, Langel Ü (2019) Recent CPP-based applications in medicine. Expert Opin Drug Deliv 16:1183-1191. https://doi. org/10.1080/17425247.2019.1665021

Landry JJM, Pyl PT, Rausch T, Zichner T, Tekkedil MM, Stütz AM, Jauch A, Aiyar RS, Pau G, Delhomme N, Gagneur J, Korbel JO, Huber W, Steinmetz LM (2013) The genomic and transcriptomic landscape of a HeLa\&nbsp;cell line. G3 GenesGenomesGenetics 3:1213-1224. https://doi.org/10.1534/g3.113.005777

Lehto T, Vasconcelos L, Margus H, Figueroa R, Pooga M, Hällbrink M, Langel $\ddot{U}$ (2017) Saturated fatty acid analogues of cell-penetrating peptide PepFect14: role of fatty acid modification in complexation and delivery of splice-correcting oligonucleotides. Bioconjug Chem 28:782-792. https://doi.org/10.1021/acs.bioconjchem.6b00680

Li H, Tsui TY, Ma W (2015) Intracellular delivery of molecular cargo using cell-penetrating peptides and the combination strategies. Int J Mol Sci 16:19518-19536. https://doi.org/10.3390/ijms160819518

Liu YF, Civelli O, Zhou QY, Albert PR (1992) Cholera toxin-sensitive 3',5'-cyclic adenosine monophosphate and calcium signals of the human dopamine-D1 receptor: selective potentiation by protein kinase A. Mol Endocrinol 6:1815-1824. https://doi.org/10.1210/ mend.6.11.1282671

Madani F, Lindberg S, Langel Ü, Futaki S, Gräslund A (2011) Mechanisms of cellular uptake of cell-penetrating peptides. J Biophys 2011. https://doi.org/10.1155/2011/414729

Maha A, Elangovan K, Chandrasekhar U, Suresh S (2016) Performance study of conical strip inserts in tube heat exchanger using water based titanium oxide nanofluid. Therm Sci 22:250-250. https:// doi.org/10.2298/TSCI151024250A

Neve KA, Seamans JK, Trantham-Davidson H (2004) Dopamine receptor signaling. J Recept Signal Transduct 24:165-205. https://doi. org/10.1081/RRS-200029981
Notredame C, Higgins DG, Heringa J (2000) T-Coffee: a novel method for fast and accurate multiple sequence alignment. J Mol Biol 302:205-217. https://doi.org/10.1006/jmbi.2000.4042

O'Callaghan K, Kuliopulos A, Covic L (2012) Turning receptors on and off with intracellular pepducins: new insights into G-proteincoupled receptor drug development. J Biol Chem 287:1278712796. https://doi.org/10.1074/jbc.R112.355461

Pandey S, Srivanitchapoom P (2017) Levodopa-induced dyskinesia: clinical features, pathophysiology, and medical management. Ann Indian Acad Neurol 20:190-198. https://doi.org/10.4103/ aian.AIAN_239_17

Pandey P, Patel V, George NV, Mallajosyula SS (2018) KELM-CPPpred: kernel extreme learning machine based prediction model for cell-penetrating peptides. J Proteome Res 17:3214-3222. https:// doi.org/10.1021/acs.jproteome.8b00322

Rueden CT, Schindelin J, Hiner MC, DeZonia BE, Walter AE, Arena ET, Eliceiri KW (2017) ImageJ2: ImageJ for the next generation of scientific image data. BMC Bioinform 18:529. https://doi. org/10.1186/s12859-017-1934-z

Saar K, Lindgren M, Hansen M, Eiríksdóttir E, Jiang Y, Rosenthal-Aizman K, Sassian M, Langel U (2005) Cell-penetrating peptides: a comparative membrane toxicity study. Anal Biochem 345:55-65. https://doi.org/10.1016/j.ab.2005.07.033

Santini E, Feyder M, Gangarossa G, Bateup HS, Greengard P, Fisone G (2012) Dopamine- and cAMP-regulated phosphoprotein of 32-kDa (DARPP-32)-dependent activation of extracellular signal-regulated kinase (ERK) and mammalian target of rapamycin complex 1 (mTORC1) signaling in experimental parkinsonism. J Biol Chem 287:27806-27812. https://doi.org/10.1074/jbc.M112.388413

Sevigny LM, Zhang P, Bohm A, Lazarides K, Perides G, Covic L, Kuliopulos A (2011) Interdicting protease-activated receptor-2-driven inflammation with cell-penetrating pepducins. Proc Natl Acad Sci USA 108:8491-8496. https://doi.org/10.1073/pnas.1017091108

Singh T, Murthy ASN, Yang H-J, Im J (2018) Versatility of cell-penetrating peptides for intracellular delivery of siRNA. Drug Deliv 25:2005-2015. https://doi.org/10.1080/10717544.2018.1543366

Sofian ZM, Shafee SS, Abdullah JM, Osman H, RAZAK SA (2014) Evaluation of the Cytotoxicity of levodopa and its complex with hydroxypropyl- $\beta$-cyclodextrin (HP- $\beta$-CD) to an astrocyte cell line. Malay J Med Sci MJMS 21:6-11

Swift ML (1997) GraphPad prism, data analysis, and scientific graphing. J Chem Inf Comput Sci 37:411-412. https://doi.org/10.1021/ ci960402j

Xicoy H, Wieringa B, Martens GJM (2017) The SH-SY5Y cell line in Parkinson's disease research: a systematic review. Mol Neurodegener 12:10. https://doi.org/10.1186/s13024-017-0149-0

Yu J, Taylor L, Mierke D, Berg E, Shia M, Fishman J, Sallum C, Polgar P (2010) Limiting angiotensin II signaling with a cell-penetrating peptide mimicking the second intracellular loop of the angiotensin II type-I receptor: limiting AT1 signaling by a cell penetrating peptide. Chem Biol Drug Des 76:70-76. https://doi.org/10.111 1/j.1747-0285.2010.00985.x

Yu J, Rupasinghe C, Wilson JL, Taylor L, Rahimi N, Mierke D, Polgar $P$ (2015) Targeting receptor tyrosine kinases and their downstream signaling with cell-penetrating peptides in human pulmonary artery smooth muscle and endothelial cells. Chem Biol Drug Des 85:586-597. https://doi.org/10.1111/cbdd.12446

Zhang P, Covic L, Kuliopulos A (2015) Pepducins and other lipidated peptides as mechanistic probes and therapeutics. Methods Mol Biol (Clifton, NJ) 1324:191-203. https://doi. org/10.1007/978-1-4939-2806-4_13

Publisher's Note Springer Nature remains neutral with regard to jurisdictional claims in published maps and institutional affiliations. 